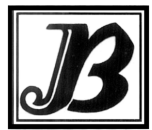

J. Bio-Sci. 29(1): 69-77, 2021 (June)

ISSN 1023-8654 http://www.banglajol.info/index.php/JBS/index DOI: https://doi.org/10.3329/jbs.v29i0.54823

\title{
PHYTOCHEMICAL ANALYSIS OF DIFFERENT PARTS OF ACALYPHA INDICA L.
}

\author{
Mim-E-Tasmim ${ }^{1}$, M Nasiruddin $^{1 *}$, MB Islam² and RS Sultana ${ }^{1}$ \\ ${ }^{1}$ Department of Botany, University of Rajshahi, Rajshahi-6205, Bangladesh \\ ${ }^{2}$ Bangladesh Council of Scientific and Industrial Research, Rajshahi, Bangladesh
}

\begin{abstract}
Acalypha indica L. is an herbaceous medicinal plant, which is grown abundantly in Bangladesh. Bangladeshi people typically use various parts of this plant for various primary healthcare treatments. The current research was conducted to check and quantify various phytochemicals and mineral components of the assorted parts of Acalypha indica L. The screening analysis shows that studied all phytochemicals were present in the leaf part but not in stem and shoot parts and some were missing or trace amount in root. Total phenol, flavonoid, and tannins content on a dry weight basis ranged from 0.53-0.82 mg GAE/g, 0.02-1.47 $\mathrm{mg} \mathrm{QE} / \mathrm{g}$ and 0.21-0.32 mg TAE/g respectively. Among the phytochemicals the leaf contains the highest amount of flavonoid (1.47 mg QE/g), and lowest in stem (0.02 mg QE/g). Similarly, the amount of minerals like $\mathrm{Fe}, \mathrm{Zn}, \mathrm{K}$ and $\mathrm{Pb}$ was $0.23-0.40 \mathrm{mg} / \mathrm{kg}, 0.01$ $0.021 \mathrm{mg} / \mathrm{kg}, 1.55-2.85 \mathrm{mg} / \mathrm{kg}$ and $0.149-0.204 \mathrm{mg} / \mathrm{kg}$ respectively. $\mathrm{K}$ was the largest volume of mineral for both leaf and stem. Lowest quantity of $\mathrm{Zn}$ was observed in most cases. This finding indicates that the studied plant might be good source of phytochemicals.
\end{abstract}

Key words: Acalypha indica, Mineral content, Phytochemical, Phytochemical screening

\section{Introduction}

Among Euphorbiaceae family Acalypha indica L. is an angiospermic plant, distributed in approximately 60 countries, and is grown widely within the tropical Africa, South Africa, and South East Asia. It grows here and there in Bangladesh like waste lands, road side's crevices in walls, rocky hillsides, forest edges and river banks. It prefers moist and shaded places (Nautiyal et al. 2015). The World health organization has estimated that $80 \%$ population of the developing countries is unable to afford the pharmaceutical drugs and depend on traditional herbal medicine to sustain their primary health care needs (Sankarnarayanan et al. 2010). The plants Acalypha indica are used medicinally in several countries and are a source of the many potent and powerful drugs (Selvamani et al. 2013). It is being employed for a protracted time as remedies for human diseases, because they contain component of therapeutic value (Nostro et al. 2000). Every part of this plant has been used as traditional medicine for long time.

Phytochemical are non-nutritive plants chemicals that have either defensive or disease protective properties. They are non-essential nutrients and mainly produced by plant to supply them protection. Here non-essential nutrients, meaning that they're not required by the physique for sustaining life (Dillard and German 2000). Agrawal (2017) investigated the phytochemical properties of Acalypha indica. Acalypha indica leaf extracts were subjected to a quantitative chemical analysis of phytochemical compounds. Another experimented with dried roots, stems, and leaves to see which had the most moisture, ash, and water activity. Acalypha indica contains a number of well-known phytochemicals. As a result, basic phytochemical analysis of plant extracts for phytoconstituents was also necessary. Based on their biosynthetic origin, phytochemicals will be divided

*Author for correspondence: mnuddin@ru.ac.bd 
into several categories; phenolics, alkaloids, steroids, tannins, saponins etc. These compounds are referred to as secondary plant metabolites and have biological properties like antioxidant activity, antimicrobial effect, and stimulation of immune system and anti-cancer property (Saxena et al. 2013).

Minerals are the nutrients that exit within the body, and are essential as our need for oxygen to sustain life. Minerals also are found in organic and inorganic combinations in plant and food. Plants are the main original source of the many drugs employed in the treatment of disease today. Currently, out of $80 \%$ of pharmaceuticals derived from plants (Haas 2006). Thus, the present study was disbursed to analysis of phytochemical and mineral compounds 6medicinal properties in order to be an honest source for production of latest drugs for various ailments.

\section{Materials and Methods}

\section{Collection of plant materials}

The whole fresh Acalypha indica plants were collected from the road sides of Rajshahi University campus and were taken to the Plant Breeding and Gene Engineering Laboratory, Department of Botany, University of Rajshahi, Bangladesh. After taxonomic identification, various parts of Acalypha indica have been considered for phytochemical investigation in the present work.

\section{Preparation of plant extracts}

The fresh whole plants were rinsed two times in tap water and finally with distilled water in order to remove debris. Then leaf, stem, flower and root parts were separated with fine knife. All these parts were air-dried in the laboratory for 5 days at $37^{\circ} \mathrm{C}$. Air dried samples were than pulverized by an electric blander into a fine powder. The air-dried powder of the plant sample was mixed by rotary evaporation with ethanol and the suspension was filtered by Whatman No.1 filter paper. Plant extracts from all parts (leaves, stem, flowers and root) were used for the qualitative, quantitative phytochemical screening.

\section{Phytochemical screening}

Qualitative determination of alkaloids, flavonoids, glycosides, saponins, tannins, steroids, phenols, and proteins from leaf, stem, flower, and root parts of Acalypha indica were screened using standard phytochemical screening procedure (Sofowora 1993).

\section{Total phenolic content (TPC)}

Folin-ciocalteu reagent method with slight modifications was used to determine phenolic content in the plant extracts which was developed by Adedapo et al. (2009) and Nabavi et al. (2008). Briefly, the reaction mixture was produced by mixing $0.5 \mathrm{ml}$ of ethanolic solution of extract, $2.5 \mathrm{ml}$ of $10 \%$ Folin-ciocalteu's reagent dissolved in water $2.5 \mathrm{ml}$ and $7.5 \% \mathrm{NaHCO}_{3}$. Blank was concomitantly Folinciocalteu's reagent dissolved in water and $2.5 \mathrm{ml}$ of $7.5 \%$ of $\mathrm{NaHCO}_{3}$. A Standard curve was prepared using gallic acid, several dilution of gallic acid in $80 \%$ ethanol were prepared viz. 20, 40,60, 80, $100 \mu \mathrm{g} / \mathrm{ml} .1 .0 \mathrm{ml}$ aliquot of each dilution was taken in a test tube and diluted with $10 \mathrm{ml}$ of distilled water. After this $2.5 \mathrm{ml}$ Folin-ciocalteu's reagent was added. This was followed by the addition of $2.5 \mathrm{ml}$ of $7.5 \% \mathrm{NaHCO}_{3}$ in each test tube. The resulting mixture was left to stand for $30 \mathrm{~min}$ at room temperature. Absorbance of the standard was measured at $765 \mathrm{~nm}$ using UV-Vis spectrophotometer (Thermo Spectronic 20, USA) against blank. The concentration of phenolics was expressed ( $\mathrm{mg} \mathrm{GAE} / \mathrm{g}$ ) from the extracts in terms of gallie acid equivalent. By using the following equation, the total phenol content was calculated. Total phenolic content = $\mathrm{GAE} \times \mathrm{V} \times \mathrm{D} / \mathrm{W}$, where $\mathrm{GAE}$ is the gallic acid equivalent $(\mathrm{mg} / \mathrm{g}) ; \mathrm{V}$ is the volume of extract $(\mathrm{ml}), \mathrm{D}$ is dilution factor and $\mathrm{W}$ is the weight $(\mathrm{g})$ of the pure plant extract. 


\section{Total flavonoids content (TFC)}

The spectrophotometric method was used to determined flavonoid developed by Quettier et al. (2000).

Briefly, $1 \mathrm{ml}$ of the ethanol extract's solution (solution concentrations were $1 \mathrm{mg} / \mathrm{ml}$ ) was added with $1 \mathrm{ml}$ of $2 \% \mathrm{AlCl}_{3}$ (ethanol). At room temperature, the samples were incubated for an hour. The spectrophotometer at $415 \mathrm{~nm}$ was used to determine the absorption. Flavonoids estimated in terms of quercetine equivalent from plant extracts. Flavonoids content $=\mathrm{QE} \times \mathrm{V} \times \mathrm{D} / \mathrm{W}$, where $\mathrm{QE}=$ quercetin equivalent $(\mathrm{mg} \mathrm{QE} / \mathrm{g}), \mathrm{V}=$ total volume of sample $(\mathrm{ml}), \mathrm{D}=$ dilution factor, $\mathrm{W}=$ samples weight $(\mathrm{g})$.

\section{Total tannin content (TTC)}

Tannins content of Acalypha indica was estimated by following the method as described by Fagbemi et al. (2005). $1.0 \mathrm{ml}$ ethanol extract were mixed with $0.5 \mathrm{ml}$ Folin-ciocalteau's reagent followed by the addition of $1.0 \mathrm{ml}$ saturated sodium carbonate $\left(\mathrm{Na}_{2} \mathrm{CO}_{3}\right)$ solution and $8.0 \mathrm{ml}$ distilled water. The reaction mixture was allowed to stand for $30 \mathrm{~min}$ at room temperature. The supernatant was obtained by centrifugation and absorbance was recorded at $725 \mathrm{~nm}$ using UV-Visible spectrophotometer. Different concentrations of standard tannic acid were prepared and the absorbance of various tannic acid concentrations was plotted for a standard graph. The tannin content was expressed as tannic acid equivalent (TAE) per gram (mg TAE/g) of the extract.

\section{Methods for mineral estimation}

The mineral assay was done as per AOAC (2005) using Atomic Absorption Spectrophotometer (AAS) (Thermo Fisher, M Series) in the Central Science Laboratory, Rajshahi University. Briefly, first plant sample digested by the following procedure of about $50 \mathrm{~g}$ of plant sample was taken from each plant parts and all samples were washed with tap water followed with de-ionized distilled water. Samples were cut into small pieces and sun dried in a concrete floor about $12 \mathrm{~h}$. After drying the samples were ground into powder from. Approximately $0.5 \mathrm{~g}$ of each sample in duplicate taken into digestion tube and to each of the tubes $5 \mathrm{ml}$ of nitric acid and $2.5 \mathrm{ml}$ of perchloric (followed by 2:1 ratio) acid was added and mixed well. The test tubes were heated to about $100^{\circ} \mathrm{C}$ for $10-12 \mathrm{~h}$ in boiling water bath and cooled. Then $2.5 \mathrm{ml}$ of nitric acid was further added to each of the tubes and heated to about 3-4 $\mathrm{h}$ in a boiling water bath till the solutions becomes transparent. The solutions were cooled and filtered through Whatman No.1 filter paper and made up to 100 $\mathrm{ml}$ with de-ionized distilled water (working standard). All the glassware's including digestion tubes were shocked with $30 \% \mathrm{HNO}_{3}$ for $8 \mathrm{~h}$ and finally washed with de-ionized distilled water. After digestion the aliquot of $14 \mathrm{ml}$ of the solution of each treatment was pipette into test tubes. A reagent blank was prepared by taking $14 \mathrm{ml}$ of de-ionized distilled water in a test tube. The absorbance and concentrations (ppm) of the solution were measured at, $371.99(\mathrm{Fe}), 307.59(\mathrm{Zn}), 766.5(\mathrm{~K})$ and $217.0(\mathrm{~Pb}) \mathrm{nm}$ in an Atomic Absorption Spectrophotometer (AAS). The amount of minerals content in the plant extract was calculated from concentrations (ppm) of the solutions. The percentage of minerals ( $\mathrm{mg} / \mathrm{kg}$ of fresh plant).

$=\frac{C \times V \times P \times T P W}{W \times M g \times P} \times D F$

Where, $\mathrm{C}=$ Concentrations $(\mathrm{ppm})$ of the solutions; $\mathrm{V}=$ Volume of stock solutions; $\mathrm{P}=$ Percentage; $\mathrm{W}=$ Weight (g) of used powder; $\mathrm{Mg}=$ Milligram factor; DF = Dilation factor and TPW = Total powder weight (in g) obtained from $1000 \mathrm{~g}$ sample. 


\section{Statistical analysis}

All experiments included at least three replications for each sample. The experimental values are given as mean, the mean were compared using Duncan's multiple-range test (DMRT) as outlined by IBM SPSS software version 20 (SPSS Inc. USA) and graphical presentation was prepared using Graph Pad Prism 6. The significance level was at $(p \leq 0.05)$.

\section{Results}

The result of the present research described in the flowing sub-heads:

\section{Qualitative phytochemicals}

This section was qualitatively examined for the screening of alkaline, flavonoid, glycoside and terpenoid, saponin, tannin, steroids, protein, carbohydrate, and phenol of Acalypha indica's ethanolic root, stem, flower and leaf extracts. The presence of secondary metabolites was indicated by "+" sign and the absence of secondary metabolites was indicated by "-" sign. "+" means trace amount, "++" means moderately present, "+++" means highly present and "-" means absent (Table 1).

The qualitative study shows that the majority of the phytochemicals are present in the root, stem, leaves and flower of Acalypha indica but exception for glycosides and steroids (Table 1). The leaf part has slight glycoside and steroids from eye views. Carbohydrate was highly present in the leaf part than flower and stem, and slightly present in root. Similarly, flavonoids were highly present in leaf, moderately in stem, but slightly in root.

Table 1. Phytochemical screening of leaf, root, stem and flower extracts of Acalypha indica

\begin{tabular}{lcccc}
\hline Phytochemicals & \multicolumn{4}{c}{ Interference } \\
\cline { 2 - 5 } & Leaf & Root & Stem & Flower \\
\hline Carbohydrate & +++ & + & ++ & ++ \\
Protein & + & - & + & + \\
Alkaloids & + & + & + & + \\
Phenol & + & + & + & + \\
Saponin & +++ & - & ++ & - \\
Tanin & +++ & + & + & ++ \\
Flavonoids & +++ & + & ++ & ++ \\
Glycoside & + & - & - & - \\
Steroids & + & - & - & - \\
Terpenoids & ++ & + & + & + \\
\hline
\end{tabular}

+ = Trace amount, $++=$ Moderately present, $+++=$ Highly present and - = Absent.

Little quantity of protein was present in the leaf, stem and flower, but absent in root. All tested parts had little amount of alkaloids, was present and same for phenol. High saponin was present in leaf and moderate in stem, but absent in root and flower. High tanin was present in leaf and moderate in flower, and little in root and stem. Terpenoids were moderately present in leaf and was little in root, stem and flower. 


\section{Quantitative phytochemicals}

Quantitative study for phenol, flavonoid, and tannins of ethanolic extract of different parts were done. Phenol, flavonoid and tannins were estimated by gallic acid, quercetin, and tannic acid equivalent respectively. Result obtained from this part has given in the flowing lines (Fig. 1).

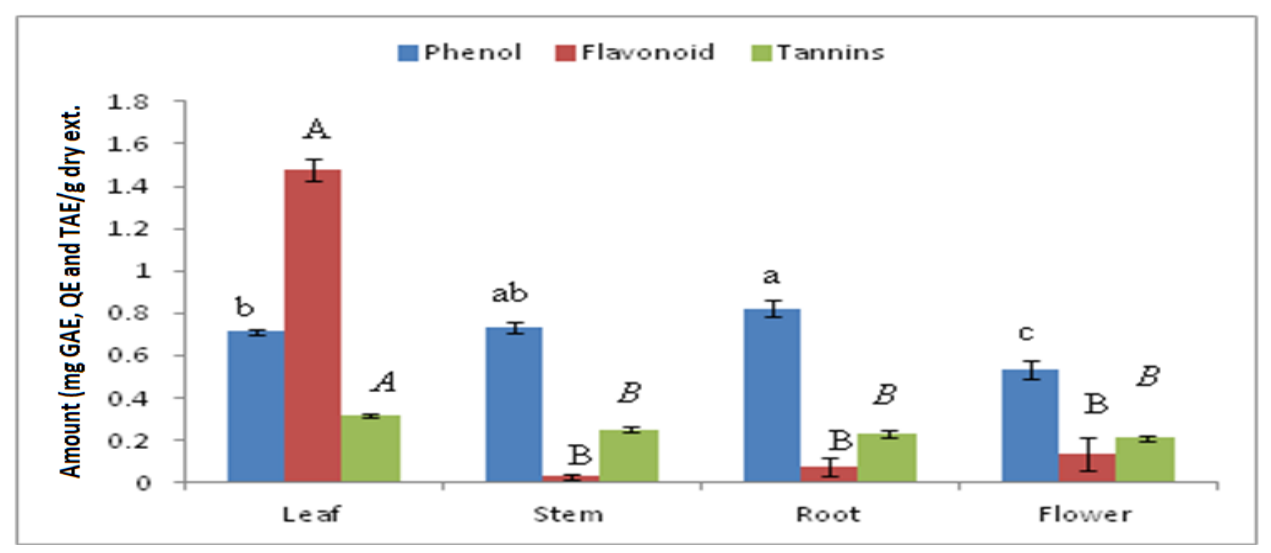

Fig. 1. Comperative phytochemicals content (mg GAE,QE and TAE equiv/g dry ext.) of phenol, flavonoid and tannins in different parts of the plant Acalypha indica L. Here, similar letter has no significant difference and different letter has significantly different of the studied bio-molecules according to DMRT. Level of significant was measured at $5 \%$.

\section{Phenol}

Highest concentration was observed in root $(0.82 \mathrm{mg} \mathrm{GAE} / \mathrm{g})$ followed by stem $(0.73 \mathrm{mg}$ GAE/g) and leaf (0.71 mg GAE/g). Lowest concentration was observed in flower (0.53 mg GAE/g) (Fig. 1). The present study reveals that root and stem has no significant different. Similarly leaf and stem has no significant difference but flower part was significantly difference among leaf, stem and root parts according to Duncan multiple range test (DMRT) (Fig. 1).

\section{Flavonoids}

The observed results showed that the highest concentration was found in leaf $(1.47 \mathrm{mg} \mathrm{QE} / \mathrm{g})$ and followed by flower $(0.13 \mathrm{mg} Q \mathrm{QE} / \mathrm{g})$ and root $(0.07 \mathrm{mg} \mathrm{QE} / \mathrm{g})$. The lowest concentration was found in stem $(0.02 \mathrm{mg}$ QE/g) (Fig. 1). Flavonoid was significantly high in stem, root and flower. On the other hand stem, root and flower part has no significant different according to DMRT (Fig. 1).

\section{Tannins}

Highest concentration of tannins was observed in leaf $(0.32 \mathrm{mg}$ TAE $/ \mathrm{g})$ and it was followed by stem $(0.25 \mathrm{mg}$ TAE $/ g$, root $(0.23 \mathrm{mg} \mathrm{TAE} / \mathrm{g})$. The lowest concentration was observed in flower (0.21 mg TAE/g) (Fig. 1). The result of the leaf part for tannins was significantly higher than stem, root and flower part. But statistically stem, root and flower part has no significant difference (Fig. 1).

\section{Minerals analysis}

In the powdered samples of the Acalyha indica, a total of four elements ( $\mathrm{Fe}, \mathrm{Zn}, \mathrm{K}$ and $\mathrm{Pb}$ ) were estimated. Result showed that, four elements had been accumulated to higher or lower levels on the different parts (root, stem, leaves, and flower) of the plant Acalypha indica. 


\section{Iron $(\mathrm{Fe})$ concentration}

Iron (Fe) concentration of different parts of Acalypha indica varied from $0.23 \mathrm{mg} / \mathrm{kg}$ to $0.40 \mathrm{mg} / \mathrm{kg}$ as dry weight basis. Results showed that the highest iron (Fe) was found in stem $(0.40 \mathrm{mg} / \mathrm{kg})$; it was followed by root $(0.311 \mathrm{mg} / \mathrm{kg})$ and flower $(0.27 \mathrm{mg} / \mathrm{kg})$. The lowest iron $(\mathrm{Fe})$ concentration was observed in leaf $(0.23$ $\mathrm{mg} / \mathrm{kg}$ ) (Fig. 2). In case of Fe concentration stem part was significantly different than leaf, root and flower part. But root and flower part has no significant different. Similarly leaf and flower has no statistically significant different (Fig. 2).

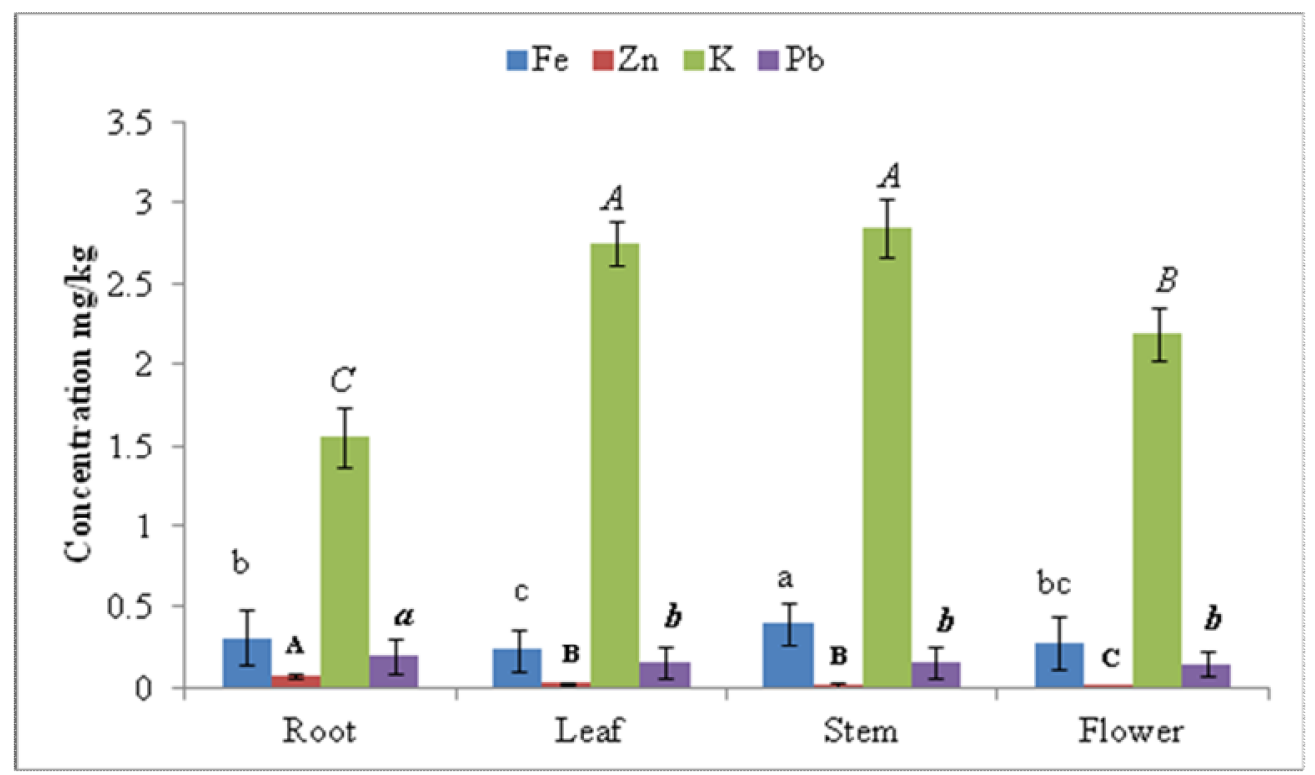

Fig. 2. Comperative minerals content (mg/kg dry wt.) of iron (Fe), zinc $(\mathrm{Zn})$, potassium $(\mathrm{K})$ and lead $(\mathrm{Pb})$ in different parts of the plant Acalypha indica L. Here, similar letter denotes no significant difference and different letter has significantly different of the studied minerals according to DMRT. Level of significant was measured at $5 \%$.

\section{Zinc $(\mathrm{Zn})$ concentration}

Among the nutrient the concentration of $\mathrm{Zn}$ ranges from $0.021 \mathrm{mg} / \mathrm{kg}$ to $0.010 \mathrm{mg} / \mathrm{kg}$. The highest concentration of $Z \mathrm{n}$ was found in the stem $(0.021 \mathrm{mg} / \mathrm{kg})$ of Acalypha indica; it was followed by leaf $(0.0175$ $\mathrm{mg} / \mathrm{kg})$ and root $(0.0174 \mathrm{mg} / \mathrm{kg})$. The lowest concentration was obtained in flower $(0.0100 \mathrm{mg} / \mathrm{kg})$ part (Fig. 2). Root, flower, leaf and stem was significantly different. Statistically leaf and stem has no significantly difference for Zn concentration (Fig. 2).

\section{Potassium (K) concentration}

The highest concentration of potassium $(\mathrm{K})$ was found in the stem $(2.85 \mathrm{mg} / \mathrm{kg})$ of Acalypha indica. It was followed by leaf $(2.75 \mathrm{mg} / \mathrm{kg})$, and flower $(2.19 \mathrm{mg} / \mathrm{kg})$. The lowest concentration was found in the root part $(1.55 \mathrm{mg} / \mathrm{kg}$ ) of Acalypha indica (Fig. 2). Leaf and stem part has no significant difference for k concentration. But root and flower was statistically significantly difference (Fig. 2). 


\section{Lead $(\mathrm{Pb})$ concentration}

Highest concentration of lead $(\mathrm{Pb})$ was found in root $(0.2042 \mathrm{mg} / \mathrm{kg})$ and it was followed by stem $(0.1564$ $\mathrm{mg} / \mathrm{kg})$, leaf $(0.1561 \mathrm{mg} / \mathrm{kg})$. Lowest was observed in flower $(0.1492 \mathrm{mg} / \mathrm{kg})$. The root part was significantly different than leaf, stem and flower. But leaf, stem and flower has no statistically difference (Fig. 2).

\section{Discussion}

Acalypha indica was chosen because it's widespread throughout the country, easy adaptation to a new condition and has a high medicinal value. Approximately 80 percent people in developed countries used medicinal plants as a traditional medicine. Knowledge of plant chemicals is desirable as such information will be valuable for the synthesis of complex chemical substances. Thus, different parts of the plants were considered and analysis for qualitative and quantitative of some phytochemicals such as phenols, flavonoids and tannins with standard protocols. Therefore, important minerals such as iron (Fe), zinc (Zn), potassium ( $\mathrm{k}$ ) and lead $(\mathrm{Pb})$ were also investigated following the Atomic Absorption Spectrophotometer (AAS).

For the treatment of various conditions, natural products have been widely used around the world since ancient times. Acalypha indica is mostly used for medicinal purposes. The flora containing flavonoids is medicinal for all parts of the plant (Nahrstedt et al. 2006). The secondary metabolites of plants have led to significant pharmacology breakthroughs and have contributed tremendously in the world (Duru and Onyedineke 2010). Medicinal plants contain some organic compounds that have a certain physiologic impact on the human body. Saponins, glycosides, tannins, alkaloids, carbohydrates, terpenoids, steroids and flavonoides contain these bioactive substances (Edoga et al. 2005). In the preliminary phytochemical testing of the Acalypha indica extracts, the presence of alkaloids, glycosides, phenols, tannins, saponins, and steroids were demonstrated according to (Kumar and Rani 2016). Preliminary organic medicines analyzes to further studies on the individual chemicals isolation and identification. In the above lines, we discussed details of some qualitative research outcome, which is in line with our current investigation. Therefore, preliminary phytochemical studies are significant and helpful for finding chemical components in plant material that lead to quantitative estimation and also for determining the source of a chemical compound that is pharmacologically active. In the present investigation also an effort was made to identify the phytochemical constituents of different parts of Acalypha indica. The results showed the presence of alkaloid, phenol, tannins, flavonoids, terpenoids, protein was absent in root, saponin was absent in root and flower, glycoside absent in root, stem, flower, similarly steroid was absent in root, stem, flower, of Acalypha indica.

Acalypha indica extracts contained a total phenolic content of $13.5 \pm 2.57 \mathrm{mg} \mathrm{GAE} / \mathrm{g}$ and a total of $49.5 \pm 0.71$ $\mathrm{mg} \mathrm{GAE} / \mathrm{g}$ was measured (Shah et al. 2003). Acalypha leaf powder studies indicate that maximum phenol content has been found to be $3.9 \mathrm{mg}$ per $100 \mathrm{~g}$ (Vijayakumari et al. 2008). These results were quite similar to the results of the present study. There is a certain similarity and dissimilarity with the phenolic concentration of different parts of Acalypha. Between root and stem there is no significant different. The root, stem, leaf and flower similarly do not differ significantly. There is no significant difference between root, stem and flower but there is a significant difference between leaf and root or stem/flower for the tannins concentration of different parts of Acalypha indica. There are many therapeutic and nutritional values in the flow of previous information of secondary metabolites. Acalypha indica may be said to have contained many important bioactive chemical components with different medicinal properties. The presence of different phytochemicals in this plant reveals that this plant can be a good source of new drug production for different ailments.

Various workers have reported mineral importance, which has raised awareness of medicinal plants for minerals (Koe and Sari 2009). The elements like Mg, Fe, K, Zn, Ca, are important medicinally. Minerals are chemical constituents used by the body in many ways. Although they yield no energy, they have important 
roles to play in many activities in the body (Malhotra 1998, Eruvbetine 2003). Herbal plants are consumed worldwide for the treatment of several diseases. As a micronutrient, heavy metal plays an essential role in proper functioning of vital organs in the human body. The concentration of Fe content in Acalypha indica was 1179.10 ppm, Zn was 12.97 ppm (Rathanavel and Arasu 2013). The concentration of Potassium in aqueous extract of Acalypha indica, leaves was $0.08 \mu \mathrm{g} / \mathrm{mg}$ (Sahayaraj and Shoba 2012). In control environment, the amount of Zinc of Acalypha indica leaf was $29.77 \mathrm{mg} / \mathrm{kg}$, stem was $48.972 \mathrm{mg} / \mathrm{kg}$, and root was 38.404 $\mathrm{mg} / \mathrm{kg}$ (Subhashini et al. 2013). The accumulation of Zinc in leaf of Acalypha indica was $20.15 \mathrm{mg} / \mathrm{kg}$, stem was $4.96 \mathrm{mg} / \mathrm{kg}$, root $92.95 \mathrm{mg} / \mathrm{kg}$ (Subhashini and Swamy 2005) on the other hand, the concentration of Zinc in different dry weight parts of Acalypha indica; root was $41.3 \mathrm{mg} / \mathrm{kg}$, leaf was $31.9 \mathrm{mg} / \mathrm{kg}$, stem was $41.3 \mathrm{mg} / \mathrm{kg}$ and Iron concentration of leaf was $213.9 \mathrm{mg} / \mathrm{kg}$. Root was $18.9 \mathrm{mg} / \mathrm{kg}$, (Rasaq et al. 2015). In the present study mineral content of different parts of Acalypha indica has some similarity and dissimilarity according to DMRT test. For the iron (Fe) content, there has some similarity between root and flower. Similarly similarity showed between leaf and flower, but there has significant difference between stem and root or leaf or flower (Fig. 2). For the Zinc (Zn) content, there has similarity among root, stem and leaf but significant difference between flower and root or stem or leaf (Fig. 2). For potassium (K) content, there has no significant difference between stem and leaf but has significant difference between root and stem or leaf. Significant difference was observed between flower and stem or leaf (Fig. 2). The results of the present study are quite difference from the previous research due to geographical difference, environmental or soil condition and methodological difference etc.

\section{Acknowledgements}

The mineral part of this research work has been carried out at Central Science Laboratory, Rajshahi University, Bangladesh and Sr. Instrument Engineer (Research \& Operation) of the same Laboratory is gratefully acknowledged for providing operational support of Atomic Absorption Spectrophotometer (AAS).

\section{References}

Adedapo A, Jomoh F, Koduru S, Masika J and Afolayan A (2009). Assessment of the medicinal potentials of the methanol extracts of the leaves and stems of Buddleja saligna. BMC Complementary and Alternative Medicine, 9: 9-21.

Agrawal T (2017). Phytochemical investigation of the Acalypha indica: A review, Research and Reviews. Journal of Pharmacognosy and Phytochemistry, 5: 41-43.

AOAC (2005). Official Methods of Analysis. 18th Ed., Association of Official Analytical Chemists, Arlington, VA, USA.

Dillard CJ and German JB (2000). Phytochemicals: Nutraceuticals and human health. Journal of the Science of Food and Agriculture, 80(12): 1744-1756.

Duru CM and Onyedineke NE (2010). In virto study on the antimicrobial activity and phytochemical analysis of ethanolic extracts of mesocarp of Voacanga Africana. American Journal of Plant Physiology, 5: 163-169.

Edeoga Ho, Okwu DE and Balbic Bo (2005). Phytochemical constituents of some Nigerian medicinal plants. African Journal of Biotechnology, 4(7): 685-688.

Eruvbetine D (2003). Canine Nutrition and Health: A paper presented at the seminar organized by Kensington Pharmaceuticals Nig. Ltd., Lagos on, August 21.

Fagbemi TN, Oshodi AA and Ipinmoroti KO (2005). Processing Effects on some Antinutritional Factors and In vitro Multienzyme Protein Digestibility (IVPD) of Three Tropical Seeds: Breadnut (Artocarpus altilis), Cashewnut (Anacardium Occidentale) and Fluted Pumpkin (Telfairia Occidentalis). Pakistan Journal of Nutrition, 4: 205- 256.

Haas EM (2006). Staying Healthy With Nutrition, 21 ${ }^{\text {st }}$ Century Ed., The Complete Guide to Diet \& Nutritional Medicine. Random House Digital, Inc. 
Koe H and Sari H (2009). Trace contents of some medicinal, aromatic plants and soil samples in the Mediterranean region, Turkey. Journal of APP Chemical and Res., (8): 52-57.

Kumar N and Rani AR (2016). Antimicrobial, antioxidant activity and phytochemical screening of Acalypha indica crude leaf extract. International Journal of Pharmaceuticals and Clinical Research, 8(6): 583-8.

Malhotra VK (1998). Biochemistry for students. Tenth Edition, Jaypee Brothers Medical publisher Ltd, New Delhi, India.

Nabavi S, Ebrahimzadeh M, Nabavi S, Hamidinia A and Bekhradnia A (2008). Determination of antioxidant activity, phenol and flavonoids content of Parrotia persica mey. Pharmacology Online, 2: 560-567.

Nahrastedt A, Hungeling M and Petereit F (2006). Flavonoids from Acalypha indica. Journal of Fitoterapia, 77(6): 484-486.

Nautiyal S, Bhaskar K and Khan YI (2015). Biodiversity of Semiarid Landscape, Springer, pp. 13-38.

Nostro A, Germano MP, Dangelo V, Marino A and Cannatelli MA (2000). Extraction methods and Bio-autography for evaluation of medicinal plant antimicrobial activity. Letters in Applied Microbiology, 30(5): 379-384.

Quettier DC, Gressier B, Vasseur J, Dine T, Brunet C, Luyckx MC, Cayin JC, Bailleul F and Trotin F (2000). Phenolic compounds and antioxidant activities of buck wheat (Fagopyrum esculentum moench) hulls and flour. Journal Ethnopharmacol, 72: 35-42.

Rasaq AO, Gregory OA, Olumayowa JO, Oladipo AL and Owolabi MS (2015). Concentration of heavy metals in root, stem and leaves of Acalypha indica and Panicum maximum Jacq from three major dumpsites in Ibadan Metropolis, South West Nigeria. American Journal of Chemistry, 5(1): 40-48.

Rathanavel C and Thillai Arasu P (2013). Quantification of heavy metals and minerals in selected Indian medicinal plants using Atomic obsorption spectrophotometer. International Journal Pharmacy and Biological Science, 4(3): 897-908.

Sahayaraj K and Shoba J (2012). Toxic effect of Tephrosia purpurea (Linn.) and Acalypha indica (Linn.) aqueous extracts impact on the mortality, macromolecules, intestinal electrolytes and detoxication enzymes of Dysdercus cingulatus (Fab.). Asian Journal of Biochemistry, 7(3): 112-122.

Sankaranarayanan S, Hhama P, Ramachandran J, Kalaichelvan PT, Vijayalakshmi M, Dhamotharan R, Dananjeyan B and Bhama S (2010). Ethnobotanical study of medicinal plants used by traditional users in Villupuram district of Tamil Nadu, India. Journal of Medicinal Plant Research, 4(12): 1089-1101.

Saxena M, Saxena J, Nema R, Singh D and Gupta A (2013). Phytochemistry of Medicinal Plants. Journal of Pharmacognosy and Phytochemistry, 1(6): 168-182.

Selvamani S, Balamuraugan S and Savitha G (2013). Preliminary phytochemical screening and anti-bacterial activity of Acalypha indica L. International Journal of Research in Biological Sciences, 3(4): 161-164.

Shah $\mathrm{H}$, Shat AA, Perveen S, Khattak S and Khattak KF (2003). Physiochemical composition of wild medicinal plant. Pakistan Journal of Applied Science, 3(6): 370-375.

Sofowora A (1993). Screening plants for bioactive agents, In: Medicinal Plants and Traditional Medicinal in Africa. 2nd Ed. Spectrum Books Ltd, Sunshine House, Ibadan, Nigeria, pp. 134-156.

Subhashini V and Swamy AWS (2005). A comparison of performance of Acalypha indica and Abutilon indicum in the removed of heavy metals from contaminated soils. International Journal of Recent Biotechnology, 3(4): 5-9.

Subhashini V, Swamy AVVS and Hema Krishna R (2013). Pot experiment: to study the uptake of zinc by different plant species in artificially contaminated soil. World Journal of Environmental Engineering, 1(2): 27-33.

Vijayakumari B, Hiranmaiya DR and Nithya SV (2008). Pharmacognostic aspect of Acalypha indica, Vitex negundo and Coriandrum sativum. Biosciences Biotechnology Research Asia, 5(1): 269-276. 